\title{
STATUS OF PEATLAND FIRE RESEARCH IN INDONESIA
}

\author{
Lailan Syaufina* \\ Department of Silviculture, Faculty of Forestry, Bogor Agricultural University (IPB), \\ Bogor, 16680, Indonesia \\ * Corresponding author: syaufinalailan@gmail.com./lailans@ipb.ac.id
}

\begin{abstract}
Peatland fire research has been on the increasing trend since 1997/1998 when fire episode experienced by Indonesia and ASEAN region. Its impact on transboundary haze pollution has not merely related to environmental but on social and political issues. Since then, research on peatland fire has been on local and global concerns. International scientific journals on peatland fire in the period of 1997-2014 were reviewed and analysed descriptively. The study shows that in the earlier stage, researches covered peatland fire characteristics, fire behaviour, fire causes and fire impacts on peat and biodiversity in limited area. Research concerns had been broadened to ecological, economical, social aspects, and even political aspects. Greater impacts on transboundary haze pollution had attracted scientists to study on haze-air pollution relationship with special concern on health and economical aspects. Moreover, peatland fire and climate change issues including greenhouse gas (GHG) emission had been covered and become an iconic topic of peatland fire studies. Geographycally, almost all peatland fire studies focused in Sumatera and Kalimantan. In the last two decades period, peatland fire researches had been explored and developed to spatial analyses on fire prone areas mapping, modelling on fire occurence prediction, haze trajectory, hotspot accuracy as fire indicator, and the latest issue was burned area estimation in relation to predict GHG emission.
\end{abstract}

Key words: peatland fire, transboundary haze, hotspot, climate change, emission

\section{INTRODUCTION}

Having the largest tropical peatland area which comprise of approximately $50 \%$ of worlds' total tropical peatlands, Indonesia plays very important role in global environmental balance. The peatland area covers $17-$ 27 million ha (Immirzi et al. 1992). Estimated extent and distribution of peatland area in Indonesia varies (Najiyati et al. 2005). However, the most recent data revealed that peatland area in Indonesia covering 14905 574 ha distributed in three main islands (Sumatera, Kalimantan, and Papua) (Ritung et al. 2011). Among the important function of the peatland are: as a large global carbon pool, regulating hydrologycal balance, biodiversity conservation, producing economicsl value of forest products, and providing livelihoods for local community. Tropical peatland covers about $10-12 \%$ of the world total peatland area, though, it store about 191 $\mathrm{Gt} \mathrm{C}$ or about one third from the total carbon storage in peatland (Page and Rieley 1998). Assuming that average peat depth of $5 \mathrm{~m}$, tropical peatland ecosystem store 2 500 ton C/hectare, compared to the average of 1200 ton C/ha in peatland in general (Diemont et al. 1997).

One of the most obvious environmental issue in Indonesia is peatland fire, which occur almost annually in Sumatera and Kalimantan particularly. Peatland fire characterized by fuel types and burning patterns, which comprised of surface fire and ground fire. When peatland surface relatively dry but water table likely to prevent fire spread, surface fire predominates the peatland area. On the other hand, when water table is low and peat moisture content less than the critical peat moisture content of about $110 \%$ to $117.39 \%$, peat fire as ground fire may predominates the peatland area
(Frandsen 1997; Syaufina et al. 2004). The surface fire is dominated by flaming combustion, while the peat fire (ground fire) is dominated by smoldering process. Since peatland has high moisture content, peatland fire produced thicker smoke called as haze and higher particulate matter content compared to non peatland fire. Therefore, the impacts of peatland fire has caused serious impacts to all aspects of ecology, economy, and social. Transboundary haze pollution has been tremendous phenomenouns in ASEAN region produced by peatland fire in 1997/1998-fire episode, which burned area estimated between 10 and 11,7 million ha (Tacconi 2003; BAPPENAS 2010), the number of people affected by smoke haze and fire were 75 million, and the total economic loss to the region was as much as US\$ 3.5 - 9.7 billion (Tacconi 2003: Barber and Schweithelm 2000). Early warning system, early detection, policy, and community empowerment are among the key elements for peatland fire control.

On the other hand, the successful of peatland fire control may be influenced by research on peatland which contribute to minimizing fire occurrences. However, it seems that publications of peatland fire in Indonesia is in limited access. Therefore, information related to peatland fire need to be elaborated and analysed. In what aspects and to what extent of the research should be important for future research direction and focus as well as peatland fire control. The paper aims to elaborate peatland fire research in Indonesia published in international journal based on research topics and authors origin classification. 


\section{METHODS}

This study applied content analyses for peatland fire research in Indonesia discourses within international journals in the period of 1997-2014, which were selected from recognized journal searching engines by using "keywords" of Peatland fire AND Indonesia as the exclusive subjects of content analyses (Bos and Tarnai 1999). Content analysis enables the investigators to include large amounts of textual information and systematically identify its properties. There are five categories requirements need to be considered in content analysis (Holsti 1969), namely: 1) categories adequately reflect the investigator's research question; 2) categories are exhaustive; 3) categories are mutually exclusive; 4) categories are independent; and 5) each category is derived from a single classification principle. To achieve the objective of the study, categories used in this study were: 1) year, 2) Research topics, and 3) Origin of authors. However, this paper will only elaborate on year and research topic categories. To determine distribution of yearly research topics and origin of authors and relationship among the categories, descriptive statistical analyses and correlation analyses were applied.

\section{RESULTS AND DISCUSSIONS}

\section{Trend of peatland fire research in Indonesia}

As forest fire occurrences in Indonesia has been on the increasing trend since the last three decades, concern and eagerness of people on the fire characteristics, causes, impacts, and control has also been in similar trend. In the period of 1984-1998, forest fire research which is reflected by undergraduate thesis of Faculty of Forestry, Bogor Agricultural University (IPB) indicated that among 32 thesis on forest fire covering areas which consist of: forest fire impacts $(37.5 \%)$, fire danger rating $(28.1 \%)$, fire season $(9.4 \%)$, fire causes $(9.4 \%)$, fire behavior $(6.3 \%)$ and fire control $(9.4 \%)$. The studies were conducted in Java, Sumatera, and Kalimantan (Syaufina 2000). Meanwhile, a recent study on the status of fire research on biodiversity and human dimension in Indonesia has revealed that fire episode in $1997 / 1998$ has broaden fire studies to ecological, economical, social aspects, and even political aspects. Peatland and climate change issues have been also included in the fire studies as well (Syaufina 2015).

Concerning research on peatland fire in Indonesia, this study found 44 research articles published in international journals. The number of articles fluctuated yearly, though, increasing trend is likely to be identified (Fig.1).

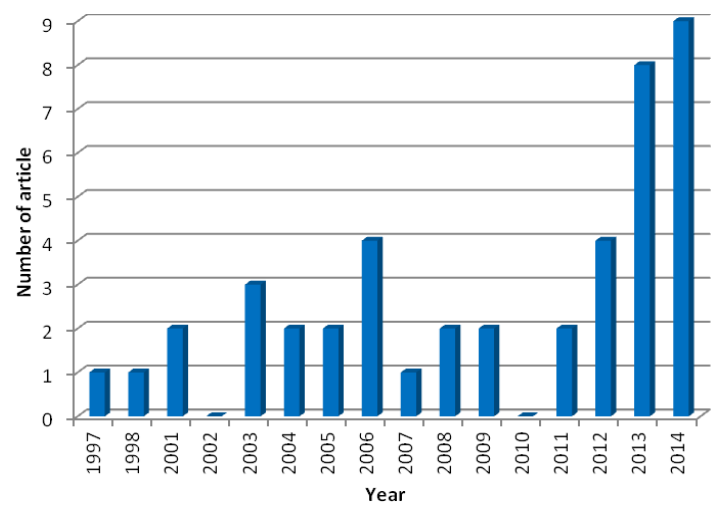

Fig. 1 Yearly distribution of number of research articles on peatland fire in Indonesia in the period of 1997-2014.

Apparently, the research articles shows significant increase in year of 2013-2014 when transboundary haze come from peatland fire in Sumatera has recurrent blanketted neighboring countries. Knowing this information, one could estimate more research on peatland fire in Indonesia will be conducted in the future.

Topics covered in peatland fire research in Indonesia

Previous studies confirmed that there are significant different of focus area on forest fire research in Indonesia. Since 1982/1983 when large forest fire devastated 3.6 million ha of tropical rain forest in East Kalimantan. The fire event seems to shock the world as tropical rain forest is known as a humid-always wet and evergreen forest can be ablazed. Since then, a great attention and concern on forest fire including impacts of the fire have been move forwards, and so did research on fire impacts. Among others, study results on fire impacts to tropical forest ecosystem have been well documented in a text book of "Fire in the Tropical Biota" (Goldammer and Seibert 1990). However, studies on fire behaviour were still limited. Forest fire had been recurrent in 1987, 1991, 1994, 1997/1998 until today (Syaufina 2015). Moreover, since 2000 studies on the impacts of fire has developed to broader sense, which involved with ecological aspect, economical aspect, as well as social aspect. Fire-carbon emission-climate related research become prominent, so did economy valuation of loss due to fire and also political issue related to policy and regulation. Forest fire studies has also been shifted to peatland management issue as one of the root problem of the smoke haze phenomenon.

Among important topics in forest fire research, it seems that topics for peatland fire research are dominated by certain topics which related to peatland fire characteristics. There are 13 research topics published in the selected journals, namely: fire-biodiversity, fire-community, fire-detection, fire-soil, fire-water, fire-smoke/haze, fire pollution, fire-hotspot, fire-policy, fire-history, fire-fuels, fire-emission, and fire-drought (Fig.2). 


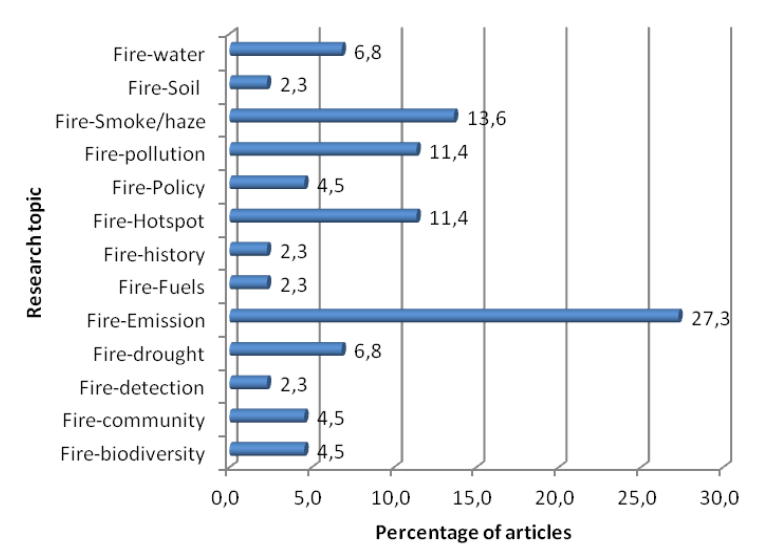

Fig. 2. Percentage of research articles based on research topics in peatland fire.

The highest percentage of research topic identified is on fire-emission $(27.3 \%)$, followed by fire-smoke/haze $(13.6 \%)$, fire-pollution $(11.4 \%)$, fire-hotspot $(11.4 \%)$, and on other research topics (less than 10\%). Undoubtedly, peatland fire produced high carbon emission, particularly $\mathrm{CO}_{2}$ which contribute greatly to climate change as the hottest environmental issue in the world since the past two decades. Moreover, smoke/haze is the most prominent issue related to peat fire as transboundary haze has been intensively addressed by high level consultation in ASEAN region, which come up with the ratification of the Agreement on Transboundary Haze Pollution by all ASEAN Member States. The research topic has been developed to high modelling estimation of smoke movement. It is in line with the topic of fire-pollution of which peatland fire produced more pollutant compared to non peatland fire, particularly carbon monoxide that could be dangerous to human health. On the other hand, research on fire indicator represented by hotspot has been of high concerned in terms of accuracy level, spatial distribution, fire prone areas, and fire prediction.

\section{CONCLUSIONS}

Research on peatland fire has been on the increasing trend since the 1997/1998-fire episode, particularly within 2013-2014 period when the research articles has significantly increased. Seemingly, it is due to prominent transboundary haze pollution impacts come from peatland fire in Sumatera and Kalimantan and the important issu related to carbon emission and global climate change. The highest percentage of research topic identified is on fire-emission $(27.3 \%)$, followed by fire-smoke/haze (13.6\%), fire-pollution (11.4\%), and fire-hotspot $(11.4 \%)$. Possible challenges on peatland fire research identified need to be enhanced for future works are: fire prediction, fire impacts on biodiversity, fire detection, fire-community, and fire prevention including zero burning implementation.

\section{REFERENCES}

BAPPENAS. 2010. The national medium term development plan 2010 - 2014. The National Development Planning Agency (BAPPENAS), Government of Indonesia, Jakarta.

Barber C, Schweithelm J. 2000. Trial by Fire: Forest Fires and Forest Policy in Indonesia's Era of Crisis and Reform, report of World Resources Institute, Forest Frontiers Initiative, in collaboration with WWF Indonesia and Telapak Indonesia Foundation.

Bos W, Tarnai C. 1999. Content analysis in empirical social research. Intrnational Journal Educational Research 31(8):659-671.

Diemont WH, Nabuurs GJ, Rieley JO, and Rijksen HD. (1997) Climate change and management of tropical peatlands as a carbon reservoir. In: J.O. Rieley \& S.E. Page (eds.) Biodiversity and Sustainability of Tropical Peatlands. Samara Publishing, Cardigan, UK. pp. 363-368.

Frandsen WH. 1997. Ignition probability of organic soils. Can. J. For. Res. 27: 1471-1477.

Goldammer JG, Seibert B. 1990. The impacts of droughts and forest fires on tropical lowland rain forest of East Kalimantan. In J. G. Goldammer ed., Fire in the tropical biota. Ecosystem Processes and Global Challenges Ecological Studies 84. Springer-Verlag. Berlin, Germany. p. 11-31.

Holsti OR. 1969. Content Analysis for the Social Sciences and Humanities. Michigan: Addison-Wesley pub.

Immirzi CP, Edward M, Richard SC. 1992. The global status of peatlands and their role in carbon cycling: a report for Friends of the Earth. Friends of the Earth.

Najiyati, S, Muslihat L, Suryadiputra INN. 2005. Panduan Pengelolaan Lahan Gambut untuk Pertanian Berkelanjutan. Proyek Climate Change, Forests and Peatlands in Indonesia. Wetlands International - Indonesia Programmed an Wildlife Habitat Canada. Bogor. Indonesia. $241 \mathrm{pp}$.

Page SE, Rieley JO. 1998. Tropical Peatlands : a Review of Their Natural Resources Functions with Particular Reference to Southeast Asia. International Peat Journal 8:95-106.

Ritung S, Wahyunto KN, Sukarman, Hikmatullah, Suparto, Tafakresnanto C. 2011. Peta Lahan Gambut Indonesia. Balai Besar Penelitian dan Pengembangan Sumberdaya Lahan Pertanian, Badan Penelitian dan Pengembangan Pertanian. Cimanggu, Bogor.

Syaufina L. 2000. The interest of studets on forest fire studies (Bogor, Indonesia). Abstracts of Group Discussions. Vol.2. Forests and Society: The Role of Research. XXI IUFRO World Congress 2000. 7 - 12 August 2000. Kuala Lumpur, Malaysia.

Syaufina L, Saharjo BH, Tiryana T. 2004. The estimation of greenhouse gases emission of peat fire. Working Paper No. 04. Environmental Research Center. Bogor Agricultural University. Bogor. 
Syaufina L. 2015. Research status on the relationship between forest fire and biodiversity and human dimension in Indonesia. A Paper presented in the National Seminar on Promoting Research on Forest and Land Fires Mitigation, Adaptation and Impact to Human and Biodiversity, SEAMEO BIOTROP, Bogor, Indonesia, 28 April 2015.
Tacconi L. 2003. Kebakaran hutan di Indonesia : Penyebab, Biaya dan Implikasi Kebijakan. CIFOR. $\mathrm{Pp} \mathrm{Vi}+28$. 